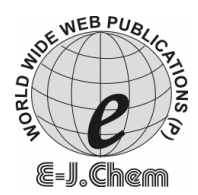

http://www.e-journals.net
ISSN: 0973-4945; CODEN ECJHAO

E-Journal of Chemistry

Vol. 5, No.4, pp. 924-929, October 2008

\title{
Physicochemical Analysis of Borewell Water Samples of Telungupalayam Area in Coimbatore District, Tamilnadu, India
}

\author{
R.SHYAMALA*, M. SHANTHI and P.LALITHA \\ Department of Chemistry, Avinashilingam University for Women, \\ Coimbatore 641043,Tamilnadu, India \\ shyamala1951@gmail.com
}

Received 5 April 2008; Revised 14 June 2008; Accepted 23 June 2008

\begin{abstract}
The dyeing units at small scale levels in the textile city of Coimbatore are ever increasing. The effluents from dyeing units play a vital role in toxicating the groundwater quality. Hence the present study was undertaken to characterize the physicochemical nature (parameters) of groundwater in Telungupalayam village in Coimbatore city by taking water samples from five different stations. Evaluation of physicochemical parameters was carried out. To assess the quality of groundwater, each parameter was compared with the standard desirable limit of that parameter in drinking water as prescribed by different agencies. A systematic calculation was made to determine the correlation coefficient ' $r$ ' amongst the parameters and the significant values of the observed correlation coefficient between the parameters was worked out. Suitable suggestions were made to improve the quality of groundwater of Telungupalayam areas.
\end{abstract}

Keywords: Water Pollution, Bore Well Water, Correlation Analysis, Telungupalayam, Dyeing Units.

\section{Introduction}

Fresh water has become a scarce commodity due to over exploitation and pollution of water. Increasing population and its necessities have lead to the deterioration of surface and sub surface water. Groundwater is the major source of drinking water in both urban and rural areas. The importance of groundwater for the existence of human society cannot be overemphasized. Besides, it is an important source of water for the agricultural and industrial sector. Till recently it had been considered a dependable source of uncontaminated water. Groundwater crisis is not the result of natural factors. It has been caused by human actions. Much of ill health which affects humanity, especially in the developing countries can be traced to lack of safe and whole some water supply. 
The quality of ground water is the resultant of all the processes and reactions that act on the water from the moment it condensed in the atmosphere to the time it is discharged by a well or spring and varies from place to place and with the depth of the water table ${ }^{1}$. Ground water is particularly important as it accounts for about $88 \%$ safe drinking water in rural areas, where population is widely dispersed and the infrastructure needed for treatment and transportation of surface water does not exist ${ }^{2}$.

Standard desirable limit of water quality parameters in drinking water prescribed by different agencies is shown in Table 1. In Coimbatore, industrialization and urbanization have major impact on groundwater environment. Both surface and subsurface water sources are getting polluted due to developmental activities. In western areas of Coimbatore, particularly in Telungupalayam (Figure 1), there are numerous dyeing and small scale industries. The effluents from these industries greatly distress the geochemistry of the soil. The discharged chemicals interact with ground water and alter the $\mathrm{pH}$ and other water quality parameters. Hence the western areas of Coimbatore were selected to study the effect of sanitary conditions on ground water quality. The social relevance of the problem has encouraged us in carrying out this work.

Table 1. Drinking water quality standards

\begin{tabular}{|c|c|c|c|c|c|c|c|c|}
\hline \multirow{2}{*}{ Parameters } & \multicolumn{2}{|c|}{ ISI (1983) } & \multicolumn{2}{|c|}{ WHO (1984) } & \multicolumn{2}{|c|}{ ICMR } & \multicolumn{2}{|c|}{ BIS } \\
\hline & HDL & MPL & HDL & MPL & HDL & MPL & HDL & MPL \\
\hline $\mathrm{pH}$ & $6.5-8.5$ & - & $7.0-8.5$ & $6.5-9.5$ & $7.0-8.5$ & $6.5-9.2$ & $7.0-8.3$ & $8.5-9.0$ \\
\hline $\mathrm{TDS}, \mathrm{mg} / \mathrm{L}$ & 500 & 2000 & - & - & 500 & 1500 & 500 & 2000 \\
\hline $\mathrm{Ca}, \mathrm{mg} / \mathrm{L}$ & - & 75 & - & 75 & - & - & - & 75 \\
\hline $\begin{array}{l}\text { Chloride, } \\
\mathrm{mg} / \mathrm{L}\end{array}$ & - & 250 & - & 250 & - & 250 & - & 250 \\
\hline $\mathrm{TH}, \mathrm{mg} / \mathrm{L}$ & 300 & 600 & 200 & 600 & 300 & 600 & 200 & 600 \\
\hline $\begin{array}{l}\text { Alkalinity, } \\
\mathrm{mg} / \mathrm{L}\end{array}$ & 200 & 600 & - & 120 & - & - & 200 & 600 \\
\hline $\mathrm{COD}, \mathrm{mg} / \mathrm{L}$ & 150 & 255 & - & 255 & - & - & 150 & 255 \\
\hline
\end{tabular}

The quality of ground water has been assessed by comparing each parameter with the standard desirable limit of that parameter in drinking water as prescribed by different agencies and sources.

\section{Experimental}

\section{Study area}

The physicochemical parameters of ground water of 5 stations in Telungupalayam viz. Thiru.V.Ka. Nagar, Veeramaariamman Kovil Street, Nedunjsezhian Street, Maasaniamman Kovil Street and Subramania Udaiyar Street (all in dyeing units) were studied. The ground water was collected from the borewells located in these stations during the months of January 2005 to March 2005. The depth of the bore wells ranged from 90-130 feet in all these stations. The sampling locations, source and corresponding habitats are shown in Table 2.

\section{Preparation of water samples}

The samples were collected in clean polythene bottles without any air bubbles. The bottles were rinsed before sampling and tightly sealed after collection and labeled in the field. 
The temperatures of the samples were measured in the field itself at the time of sample collection. The samples were kept in refrigerator maintained at $4^{\circ} \mathrm{C}$.

Table 2. Sampling locations and corresponding habitats

\begin{tabular}{clcc}
\hline S.No & \multicolumn{1}{c}{ Sampling Locations } & Habitat & Source \\
\hline 1. & Thiru.V.Ka Nagar & Residential Area & Borewell \\
2. & Veeramaariamma Kovil Street & Residential Area & Borewell \\
3. & Nedunjsezhian Street & Residential Area & Borewell \\
4. & Maasaniamman Kovil Street & Commercial Area & Borewell \\
5. & Subhramania Udaiyar Street & Commercial Area & Borewell \\
\hline
\end{tabular}

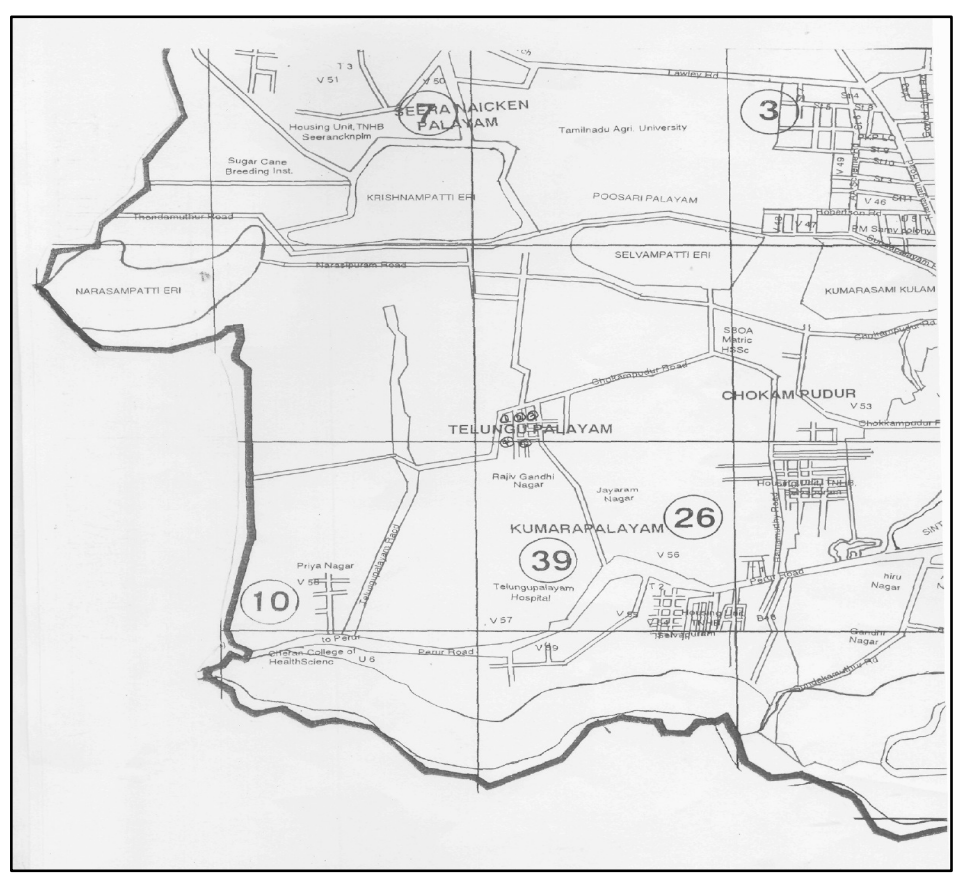

Figure 1. Map of study area (Telungupalayam)

\section{Analysis of water sample}

Analysis was carried out for various water quality parameters such as $\mathrm{pH}$, total dissolved solids, total hardness, total alkalinity, calcium, chloride and chemical oxygen demand (COD) as per standard procedures.

\section{Determination of water quality parameters}

The water quality parameters analysed were; $\mathrm{pH}$ - measured using standard $\mathrm{pH}$ meter, total dissolved solids (TDS) by standared methods ${ }^{3}$, calcium content by EDTA titrimetric method, chloride content by argentometric method, total hardness (TH) by EDTA titrimetric method, methyl orange alkalinity and chemical oxygen demand (COD) by open reflux method

\section{Statistical analysis}

The simple linear correlation analysis has been carried out to find out correlation between any two tested parameters. The significance of correlation was also tested. 


\section{Results and Discussion}

The results of the physicochemical analysis of the groundwater samples S1 to S5, collected from 5 places in Telungupalayam are presented in Table 3.

$p H$

$\mathrm{pH}$ is considered as an important ecological factor and provides an important piece factor and piece of information in many types of geochemical equilibrium or solubility calculation. $\mathrm{pH}$ is an important parameter in water body since most of the aquatic organisms are adapted to an average $\mathrm{pH}$ and do not withstand abrupt changes.

The $\mathrm{pH}$ values fluctuated between 7.5 to 8.4 (Table 3). The limit of $\mathrm{pH}$ value for drinking water is specified ${ }^{4}$ as 6.5 to 8.5 . The $\mathrm{pH}$ shows slightly alkaline trend. Generally $\mathrm{pH}$ of water is influenced by geology of catchments area and buffering capacity of water.

\section{Temperature}

The temperature was found to be in the range between 26.3 to $27.2^{\circ} \mathrm{C}$ during study. The higher value of water temperature observed in the present study could be attributed to the early summer months prevailed during the period of investigation.

\section{Total alkalinity}

The standard desirable limit ${ }^{5}$ of alkalinity in potable water is $120 \mathrm{mg} / \mathrm{L}$. The maximum permissible level is $600 \mathrm{mg} / \mathrm{L}$. The mean value of alkalinity in the ground water of Telungupalayam area was $150.85 \mathrm{mg} / \mathrm{L}$ (Table 3) which exceeded the desirable limit in all stations.The value of alkalinity in water provides an idea of natural salts present in water. The cause of alkalinity is the minerals which dissolve in water from soil. The various ionic species that contribute to alkalinity include bicarbonate, hydroxide, phosphate, borate and organic acids. These factors are characteristics of the source of water and natural processes taking place at any given time ${ }^{6}$. The small scale dyeing units present in Telungupalayam do not have proper drainage system. They discharge the waste waters into the soil. This may lead to increase in alkalinity of ground water in these areas.

Table 3. Comparison of physicochemical parameters of groudnwater, Telungupalayam area (in $\mathrm{mg} / \mathrm{L}$ ) with standard values (WHO)

\begin{tabular}{cccccccc}
\hline Parameters & $\mathrm{S}_{1}$ & $\mathrm{~S}_{2}$ & $\mathrm{~S}_{3}$ & $\mathrm{~S}_{4}$ & $\mathrm{~S}_{5}$ & Mean & WHO \\
\hline $\mathrm{pH}$ & 7.0 & 8.4 & 8.13 & 8.10 & 7.5 & 8.0 & $7.0-8.5$ \\
Temperature, ${ }^{\circ} \mathrm{C}$ & 26.3 & 26.7 & 26.8 & 27.1 & 27.5 & 26.9 & - \\
TDS & 386.20 & 285.00 & 217.00 & 149.00 & 651.00 & 337.64 & 500 \\
Calcium & 49.12 & 39.48 & 40.12 & 7.86 & 71.76 & 41.67 & 75 \\
Chloride & 190.90 & 148.04 & 128.80 & 60.70 & 276.84 & 162.26 & 250 \\
$\mathrm{TH}$ & 235.56 & 160.24 & 158.64 & 94.55 & 171.46 & 164.09 & 200 \\
Alkalinity & 177.75 & 163.34 & 124.91 & 153.73 & 134.52 & 150.85 & 120 \\
COD & 8 & 8 & 16 & 8 & 16 & 11.2 & 255 \\
\hline
\end{tabular}

Chloride

Chlorides are important in detecting the contamination of ground water by waste water. The permissible limit ${ }^{5}$ of chloride in drinking water is $250 \mathrm{mg} / \mathrm{L}$. The values of chloride observed in $\mathrm{S}_{1}, \mathrm{~S}_{2}, \mathrm{~S}_{3}$ and $\mathrm{S}_{4}$ were very low i.e. within the permissible limit, whereas the chloride value observed in $S_{5}$ was well above the standard desirable limits prescribed by WHO (1984). The presence of chloride in slightly higher amounts in $S_{5}$ may be due to natural processes such as the passage of water through natural salt formations in the earth or it may be an indication of pollution from industrial or domestic use ${ }^{7}$. 


\section{Total hardness (TH)}

ISI has specified the total hardness to be within $300 \mathrm{mg} / \mathrm{L}$ of $\mathrm{CaCO}_{3}$. Regarding total hardness fluctuating trends in its value were observed in all the 5 stations. The observed total hardness values were well within the limits. $\mathrm{S}_{1}$ has comparatively high $\mathrm{TH}$ value (235.5 mg/L) than $\mathrm{S}_{4}(94.5 \mathrm{mg} / \mathrm{L})$.

\section{Total dissolved solids (TDS)}

The average value of TDS in the ground waters of Telungupalayam was $337.64 \mathrm{mg} / \mathrm{L}$. ISI prescribed the desirable limit of TDS is $500 \mathrm{mg} / \mathrm{L}$. The maximum permissible level is 2000 $\mathrm{mg} / \mathrm{L}$. TDS values observed in $\mathrm{S}_{1}, \mathrm{~S}_{2}, \mathrm{~S}_{3}$ and $\mathrm{S}_{4}$ were within the desirable limit but the TDS value observed in $S_{5}$ was well above the standard desirable limit. High TDS in ground water may be due to ground water pollution when waste waters from both residential and dyeing units are discharged into pits, ponds and lagoons enabling the waste migrate down to the water table ${ }^{8}$.

\section{Calcium}

Calcium concentrations were found to vary from 7 to $71 \mathrm{mg} / \mathrm{L}$. The upper limit of calcium concentration for drinking water is specified as $75 \mathrm{mg} / \mathrm{L}$ (ISI, 1983). The calcium hardness observed in all the 5 stations are well within the desirable limits with a minimum of 7.86 $\mathrm{mg} / \mathrm{L}$ in $\mathrm{S}_{4}$ to a maximum of $71.76 \mathrm{mg} / \mathrm{L}$ in $\mathrm{S}_{5}$.

\section{Chemical Oxygen demand (COD)}

The observed COD values in all the 5 stations are varying from 8 to $16 \mathrm{mg} / \mathrm{L}$. The permissible limit of COD for drinking water is $255 \mathrm{mg} / \mathrm{L}$. Hence the observed COD values in all the 5 stations are well within the desirable limit.

\section{Statistical Analysis}

\section{Correlation Studies}

Interrelationship studies between different variables are very helpful tools in promoting research and opening new frontiers of knowledge. The study of correlation reduces the range of uncertainty associated with decision making.

The correlation co-efficient ' $r$ ' was calculated using the equation

$$
r=\frac{\Sigma x y}{\sqrt{\Sigma x^{2} x \Sigma y^{2}}}
$$

where $\quad \underline{X}=X-\bar{X}$ and $y=Y-\bar{Y}, X$ and $Y$ represent two different parameters $\bar{X}=$ Mean value of $X ; \bar{Y}=$ Mean value of $Y$

The correlation co-efficient (r) among various water quality parameters are given in Table 4 .

Table 4. Correlation matrix for the water quality parameters

\begin{tabular}{ccccccccc}
\hline Parameters & $\mathrm{pH}$ & Chloride & Calcium & Alkalinity & TH & TDS & COD & Temp \\
\hline pH & 1.00 & $-0.743^{*}$ & $-0.649^{*}$ & 0.229 & -0.329 & $-0.815^{*}$ & -0.500 & -0.477 \\
Chloride & & 1.00 & $0.976^{*}$ & -0.079 & $0.658^{*}$ & $0.975^{*}$ & 0.460 & 0.234 \\
Calcium & & & 1.00 & -0.191 & $0.678^{*}$ & $0.915^{*}$ & 0.567 & 0.180 \\
Alkalinity & & & & 1.00 & 0.396 & -0.113 & $-0.903^{*}$ & $-0.658^{*}$ \\
TH & & & & & 1.00 & 0.503 & 0.018 & -0.567 \\
TDS & & & & & & 1.00 & 0.449 & 0.408 \\
COD & & & & & & 1.00 & 0.548 \\
Temperature & & & & & & & 1.00 \\
\hline
\end{tabular}

* Significant at $5 \%$ level, $r>0.649$ 


\section{Test of significance of the observed correlation coefficients}

The significance of the observed correlation coefficients have been tested by using ' $t$ ' test. Out of the total 28 correlations found between two parameters, 10 were found to have significant at 5\% level $(\mathrm{r}>0.649)$. The negative (inverse) correlations were found in 12 cases between $\mathrm{pH}$ and chloride $(\mathrm{r}=-0.743)$, between $\mathrm{pH}$ and calcium $(\mathrm{r}=-0.649)$, between $\mathrm{pH}$ and total hardness $(\mathrm{r}=-0.329)$, between $\mathrm{pH}$ and total dissolved solids $(\mathrm{r}=-0.815)$, between $\mathrm{pH}$ and COD $(\mathrm{r}=-0.500)$, between $\mathrm{pH}$ and temperature $(\mathrm{r}=-0.477)$, between chloride and total alkalinity $(r=-0.079)$, between calcium and total alkalinity $(r=0.191)$, between total alkalinity and TDS $(r=-0.113)$, between total alkalinity and temperature $(r=$ $-0.658)$ between total alkalinity and COD $(r=0.903)$, and between total hardness and temperature $(\mathrm{r}=-0.567)$. Some of the highly significant correlations were discernible between chloride and calcium $(r=0.976)$, chloride and TDS $(r=0.975)$ and between calcium and TDS $(r=0.915)$. Total hardness did not show any significant correlations with TDS, COD and temperature. Similarly TDS did not show any significant correlation with COD and temperature.

\section{Conclusion}

The analysis of the water quality parameters of groundwater from five different stations in Telungupalayam village in the Coimbatore city shows that the $\mathrm{pH}$, chloride ion, total hardness, calcium and COD values are well within the permissible limits. The TDS of $\mathrm{S}_{5}$ was well above the desirable limit and the average of alkalinity has exceeded the desirable limits which are due to improper drainage system of the dyeing units. In conclusion from the results of the present study it may be said that the groundwater of Telungupalayam is though fit for domestic and drinking purpose need treatments to minimize the contamination especially the alkalinity.

The values of correlation coefficients and their significance levels will help in selecting the proper treatments to minimize the contaminations of groundwater of Telungupalayam. There is an increasing awareness among the people to maintain the groundwater at their highest quality and purity levels and the present study may prove to be useful in achieving the same.

\section{Acknowledgement}

The authors thank the concerned authorities of the Avinashilingam University for Women, Coimbatore, for providing facilities to carry out this work.

\section{References}

1. Jain CK, Bhatia KKS and Vijay T, 1995. Ground water quality monitoring and evaluation in and around Kakinada, Andhra Pradesh, Technical Report,CS (AR) 172, National Institute of Hydrology, Roorkee, 1994- 1995.

2. Kumar A, Water Pollution. Nisha Enterprises New Delhi. 2004, pp 1-331.

3. APHA, Standard methods for the examination of water and waste water, American Public Health Association, Washington, 1989.

4. ISI, Indian Standard specification for drinking water, IS10500, ISI, New Delhi, 1983.

5. W.H.O, Guidelines for drinking water quality, Vol.1, Recommendations WHO, Geneva, 1984.

6. Sharma M R, J Pollut Res., 2004, 23(1), 131-134.

7. Renn C E, Investigating water problems, Educational Products Division, LaMotte Chemical Products Company, Maryland,1970.

8. Rani, D F G, Geetha S and Ebanazar, J Pollut Res., 2003, 22(1), 111-115. 


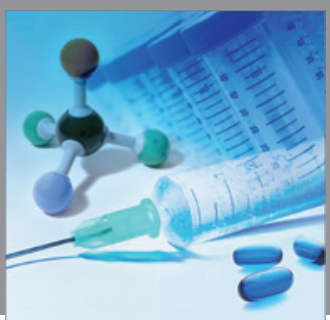

International Journal of

Medicinal Chemistry

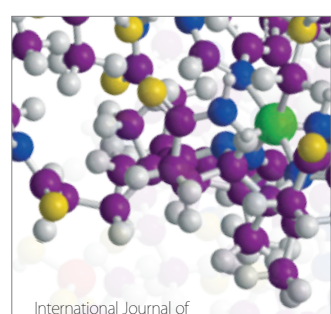

Carbohydrate Chemistry

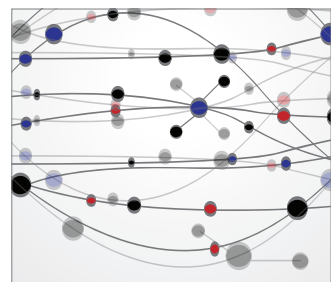

The Scientific World Journal
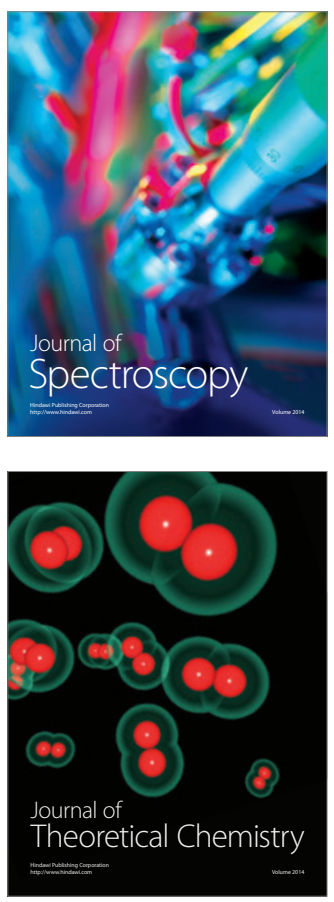
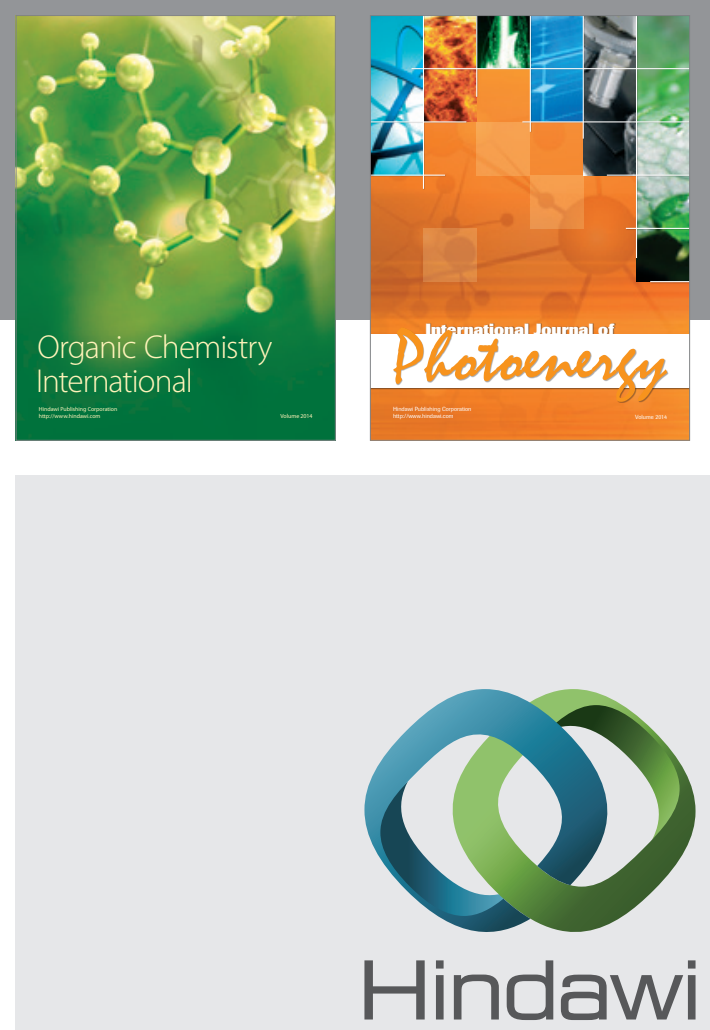

Submit your manuscripts at

http://www.hindawi.com
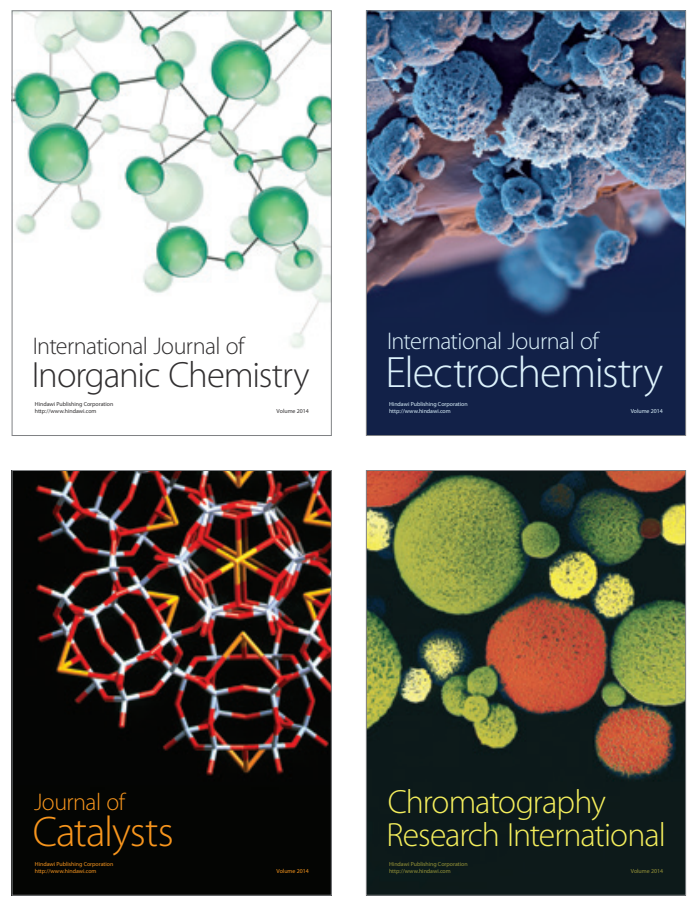
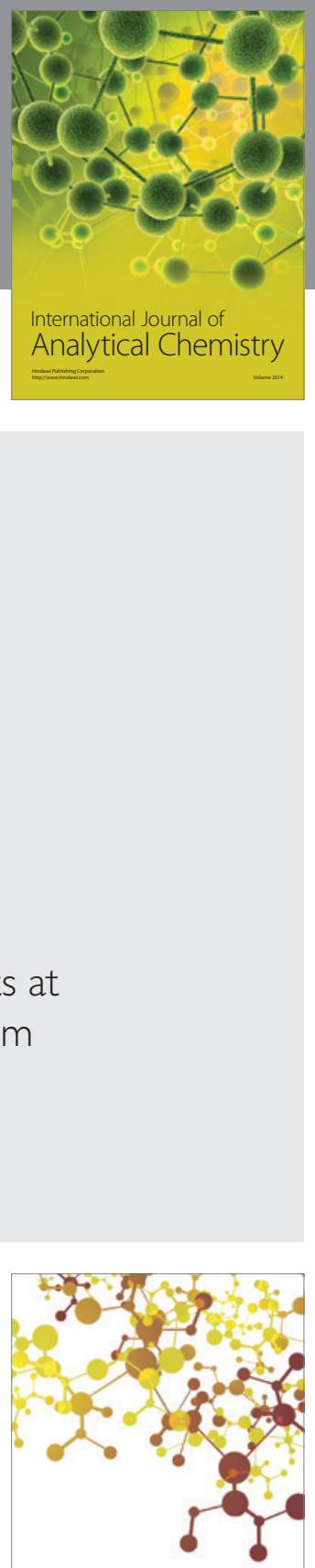

Journal of

Applied Chemistry
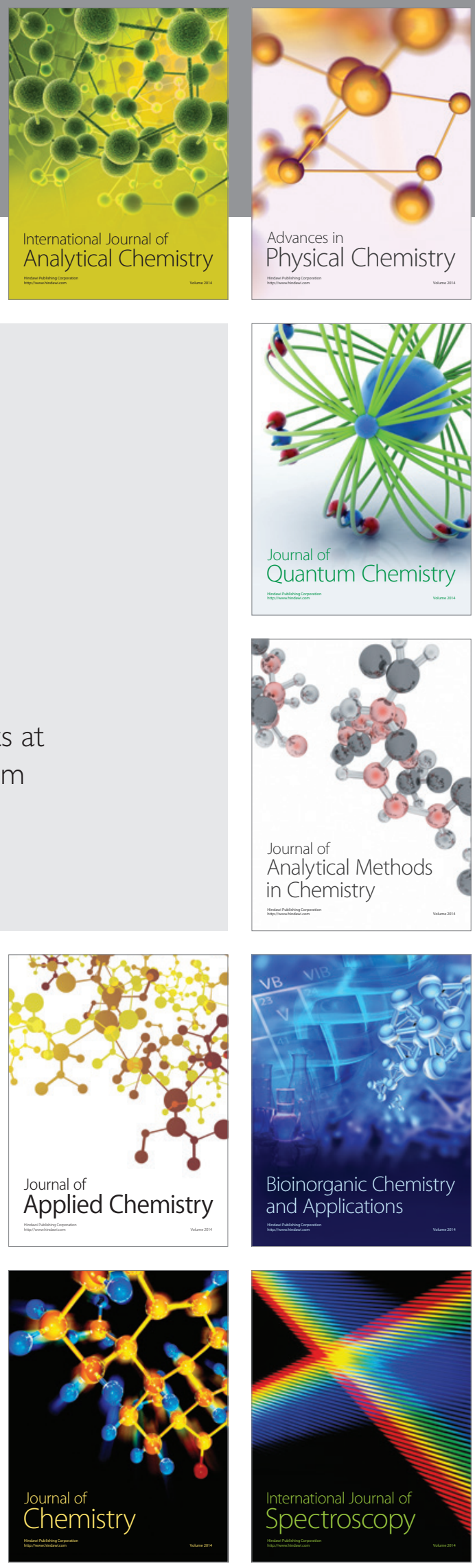